\title{
STRATEGI PENANGGULANGAN NYERI BENDUNGAN ASI PADA IBU NIFAS
}

\author{
Coping Strategy of Pain on Breast Engorgement in Postpartum Mother
}

\author{
Pande Putu Indah Purnamayanti ${ }^{1}$, Made Ririn Sri Wulandari ${ }^{2}$ \\ ${ }^{1}$ Program Studi D3 Kebidanan, STIKES Bina Usada Bali, Badung, Bali, Indonesia \\ ${ }^{2}$ Departemen Keperawatan Maternitas, Program Studi S1 Keperawatan, STIKES Bina Usada Bali, \\ Badung, Bali, Indonesia \\ Korespondensi : pandeindah25@gmail.com
}

\begin{abstract}
ABSTRAK
Bendungan ASI merupakan suatu kondisi yang tidak menyenangkan yang dialami sebagian besar wanita pada periode nifas. Bendungan ASI yang tidak diatasi dapat menghambat proses menyusui, seperti nyeri pada payudara dan komplikasi yang lanjut, seperti infeksi payudara. Penelitian ini bertujuan untuk mengeksplorasi strategi penanggulangan nyeri bendungan ASI pada ibu nifas di wilayah kerja Puskesmas Pembantu Desa Penarukan, Kecamatan Kerambitan, Kabupaten Tabanan. Desain penelitian yang digunakan adalah kualitatif dengan menggunakan pendekatan perspektif fenomenologis. Pengambilan sample menggunakan purposive sampling dengan jumlah 6 responden yang mengalami bendungan ASI sejak hari ketiga sampai hari kesepuluh nifas. Hasil penelitian dari analisis data menunjukkan terdapat metode penanggulangan bervariasi untuk mengatasi nyeri yang disebabkan oleh bendungan ASI. Perlakuan yang dilakukan seperti melakukan pompa ASI, massage, melakukan kompres hangat dan melakukan kompres dingin. Kesimpulan hasil penelitian ini menunjukkan bahwa nyeri dapat menurun dengan menggunakan strategi penanggulangan medik dan non medik. Rekomendasi selanjutnya untuk lebih mengeksplorasi terkait nilai-nilai budaya yang diyakini pada ibu nifas dalam proses menyusui.
\end{abstract}

Kata kunci : strategi penanggulangan, bendungan ASI, nyeri

\begin{abstract}
Breast engorgement are an unpleasant condition experienced by most women during the postpartum period. Breast Engorgement can hamper the breastfeeding process, such as breast pain and advanced complications, such as breast infections. This study aims to explore strategies for overcoming pain on breast engorgement postpartum mothers in the work area Puskesmas Pembantu Desa Penarukan, Kecamatan Kerambitan, Kabupaten Tabanan. The research design used a qualitative study using a phenomenological perspective approach. Sample was taken by using purposive sampling, and it was found that 6 respondents experienced breast engorgement from the third day to the tenth day of the puerperium. Results of the research from the data analysis showed that there were various coping methods to deal with pain caused by breast engorgement. Treatments such as doing breast pumps, massage, doing warm compresses and doing cold compresses. Conclusions of this study indicate that pain can be reduced by using medical and non-medical coping strategies. The next recommendation is to further explore the cultural values that are believed in postpartum mothers in the breastfeeding process.
\end{abstract}

Keywords : coping strategies, breast engorgement, pain 


\section{PENDAHULUAN}

Masa nifas merupakan sebuah proses pemulihan ibu setelah masa kehamilan dan persalinan yang berlangsung selama 6 minggu yang ditandai dengan perubahanperubahan fisiologis salah satunya adalah pengeluaran air susu ibu (Elvira \& Panjaitan, 2017). Pada masa nifas, ibu melakukan proses menyusui yang merupakan metode pemenuhan kebutuhan nutrisi pada bayi. Ibu menyusui memiliki harapan dapat memberikan air susu ibu (ASI) dengan lancar, namun banyak fenomena ibu tidak dapat menyusui bayi yang disebabkan oleh masalah pada payudara (Astutik, 2014). Masalah pada payudara selama masa menyusui dapat menjadi salah satu tanda bahaya pada masa nifas (Kementerian Kesehatan RI, 2015). Permasalahan pada payudara yang sering dialami ibu menyusui antara lain salah satunya adalah payudara bengkak (Mansyur \& Dahlan, 2014).

Payudara bengkak salah satunya disebabkan karena menyusui yang tidak berkesinambungan, sehingga sisa ASI terkumpul pada daerah duktus. Penggunaan bra yang ketat serta tidak bersihnya putting susu mengakibatkan sumbatan pada duktus (Santoso, Kusmiyati, \& Margono, 2016). Pembengkakan payudara akan menyebabkan terjadinya bendungan air susu ibu (ASI), akibatnya bayi tidak mendapatkan ASI secara eksklusif. Survei Demografi Kesehatan Indonesia menyebutkan, ibu nifas yang mengalami masalah bendungan ASI mencapai 77.231 orang $(37,12 \%)$ (Kementerian Kesehatan Republik Indonesia, 2016).

Ibu yang mengalami masalah dalam menyusui akan berdampak pada pemberian ASI eksklusif pada bayi. Fenomena bendungan ASI ibu dapat menghambat proses menyusui sehingga menimbulkan hubungan yang kurang erat antara ibu dan anak. Selain itu, bendungan ASI mengakibatkan peradangan pada payudara ibu dan secara palpasi teraba keras, kadang terasa nyeri serta seringkali disertai peningkatan suhu badan ibu, dan terdapat tanda-tanda kemerahan dan demam (Manuaba, 2010).

Rata-rata ibu menyusui dengan masalah bendungan ASI mengalami nyeri dengan kisaran skala 6-8 (nyeri berat) dan skala 3-5 (nyeri sedang). Nyeri pada payudara diakibatkan oleh meningkatnya aliran vena dan limfe akibat penyempitan duktus laktiferi (Meihartati, 2017). Selain itu nyeri payudara diakbiatkan oleh meregangnya jaringan mammae akibat pembengkakan yang menekan reseptor nyeri (Wahyuni, 2018). Berbagai strategi penanggulangan dan adaptasi dilakukan ibu sebagai upaya mengatasi nyeri yang diakibatkan oleh bendungan ASI. Untuk itu, perlu dilakukan penelusuran fenomena strategi penanggulangan nyeri yang diakibatkan oleh bendungan ASI pada ibu yang menjalani masa nifas

\section{TUJUAN PENELITIAN}

Penelitian ini bertujuan untuk mengeksplorasi strategi penanggulangan ibu mengatasi bendungan ASI.

\section{METODE PENELITIAN}

\section{Desain}

Dalam penelitian ini digunakan desain kualitatif dengan menggunakan pendekatan perspektif fenomenologis. Pendekatan ini dilakukan untuk memahami pengalaman subyek dengan menekankan pada pencarian suatu fenomena, intensionalitas kesadaran, analisa data melalui reduksi, serta menyingkirkan prasangka pada fenomena yang diteliti.

\section{Populasi dan Partisipan}

Populasi dalam penelitian ini adalah ibu nifas di wilayah kerja Puskesmas Pembantu Desa Penarukan, Kecamatan Kerambitan, Kabupaten Tabanan. Penelitian ini melibatkan 6 partisipan yang mengalami bendungan ASI sejak hari ketiga sampai hari kesepuluh nifas yang diambil dengan teknik pengambilan sampel purposive. Partisipan diperoleh melalui skrining pada data ibu yang melakukan kunjungan di Puskesmas Pembantu Penarukan.

\section{Tempat dan Waktu Penelitian \\ Penelitian ini dilaksanakan di Puskesmas Pembantu Desa Penarukan}


Pande Putu Indah Purnamayanti : Strategi Penanggulangan Nyeri Bendungan ASI Pada Ibu Nifas

Kecamatan Kerambitan, Kabupaten Tabanan. Penelitian dilakukan selama 6 bulan.

\section{Instrumen dan Prosedur Pengukuran}

Instrument yang digunakan dalam penelitian ini adalah sebuah handphone yang dilengkapi dengan voice recorder, petunjuk umum wawancara, daftar pertanyaan wawancara, dan lembar catatan wawancara.

\section{Metode Pengumpulan Data}

Wawancara terbuka dilakukan dengan menggunakan petunjuk umum wawancara denga alat bantu handphone yang dilengkapi dengan voice recorder. Seain itu, pengumpulan data sekuder dilakukan melalui observasi rekam medik ibu selama menjalani perawatan, serta catatan harian yang dibuat selama ibu mengalami masalah bendungan ASI melalui persetujuan dan kesediaan ibu.

\section{Analisa Data}

Adapun langkah yang dilakukan dalam analisa data yaitu membuat data yang sudah dikumpulkan, mevalidasi data dari partisipan, mendeskripsikan pengalaman peneliti, melakukan triangulasi, melakukan transferabilitas, melakukan dependabilitas, melakukan konfirmabilitas dengan cara mengkonfirmasi data mentah, hasil analisis data, hasil sintesis data, dan catatan mengenai proses yang digunakan.

\section{HASIL PENELITIAN}

Partisipan dalam penelitian ini berjumlah 6 orang ibu nifas yang diwawancarai pada hari kelima nifas. Rentang usia ibu adalah 20-32 tahun, jumlah kehamilan berada pada rentang kehamilan pertama sampai kehamilan ketiga. Rata-rata skala nyeri pada bendungan payudara yang dirasakan adalah skala 5,3. Adapun hasil penelitian ini sebagai berikut:

\section{Strategi penanggulangan nyeri dengan intervensi medis.}

"Tenaga kesehatan memberikan obat penghilang nyeri...." (P1, usia 21 tahun, persalinan ke-1; P4, usia 26 tahun, persalinan ke-1; P6, usia 27 tahun, persalinan ke-1).

\section{Strategi penanggulangan nyeri dengan intervensi non-medis.}

"Saya melakukan pompa ASI dengan bantuan alat pompa manual..." (P2, usia 30 tahun, persalinan ke-2)

"Saya melakukan massase payudara dan memompa ASI dengan bantuan alat elektrtik..." (P3, usia 32 tahun, persalinan ke-3).

"Saya memberikan kompres hangat dan kompres dingin..." (P5, usia 32 tahun, persalinan ke-1).

\section{PEMBAHASAN}

Partisipan dalam penelitian ini menggunakan pendekatan berbeda untuk mengatasi masalah nyeri pada payudara yang disebabkan oleh bendungan ASI. 3 partisipan mengatasi nyeri dengan mengkonsumsi obat yang diresepkan oleh tenaga kesehatan, 1 orang partisipan melakukan pompa untuk mengeluarkan ASI yang bertujuan mengurangi bendungan sehingga nyeri dapat berkurang. 1 orang partisipan melakukan teknik massase payudara dan melakukan pompa asi dengan bantuan alat elektrik, serta 1 partisipan melakukan kompres hangat dan kompres dingin untuk mengurangi bendungan ASI.

Partisipan melakukan beberapa metode penanggulangan yang bervariasi untuk mengatasi nyeri yang disebabkan oleh bendungan ASI. Perlakuan yang dilakukan seperti melakukan pompa ASI, massage, melakukan kompres hangat dan melakukan kompres dingin, sesuai dengan teori yang dikemukakan oleh Lawrence \& Lawrence (2010) bahwa menekan payudara, memompa ASI, melakukan kompres dingin dan menggunakan obat-obatan merupakan beberapa solusi mengatasi nyeri pada bendungan ASI. Lebih lanjut dijelaskan teknik non-medis dapat menekan stimulasi pada payudara seperti menggunakan kompres hangat dan kompres dingin (Cole, 2012; Lawrence \& Lawrence, 2010). 
Partisipan dalam penelitian ini juga menggunakan teknik massage, yang menunjukkan perubahan penurunan nyeri. Hasil penelitian ini didukung oleh penelitian yang dilakukan Witt, Bolman, Kredit, \& Vanic (2016), yang menyebutkan seluruh wanita yang dilibatkan sebagai responden mengalami penurunan tingkat nyeri. Setelah 12 minggu dilakukan massage, 65\% dilaporkan pemberian massage sangat membantu mengatasi nyeri.

\section{Implikasi}

Nyeri pada penelitian ini menurun dengan menggunakan penanggulangan medik dan non-medik. Pada teknik nonmedik, partisipan menggunakan teknik pumping, massage, serta menggunakan kompres hangat dan dingin. Penelitian ini dapat menjadi dasar pelaksanaan penelitian berupa pemberian perlakuan non-medik dalam menangani nyeri pada massalah bendungan ASI.

\section{Keterbatasan}

Peneliti tidak menggali nilai-nilai yang diyakini oleh partisipan dalam mengatasi masalah nyeri pada masalah bendungan payudara. Penelitian selanjutnya dapat melakukan eksplorasi terkait nilainilai budaya yang diyakini pada ibu nifas.

\section{DAFTAR PUSTAKA}

Astutik, R. Y. (2014). Payudara dan Laktasi. Jakarta: Salemba Medika.

Cole, M. (2012). Lactation after Perinatal, Neonatal, or Infant Loss. Clinical Lactation, 3, 94-100. https://doi.org/10.1891/215805312807 022897

Elvira, D., \& Panjaitan, A. A. (2017). Hubungan Antara Pengetahuan Ibu Nifas Dengan Sikap Dalam Melakukan Perawatan Payudara di Rumah Sakit Kartika Husada Kabupaten Kubu Raya Tahun 2017. Jurnal Kebidanan, 7(1), $55-62$.

Kementerian Kesehatan Republik Indonesia. (2016). Profil Kesehatan Indonesia Tahun 2015. (D. Budjianto, Yudianto, B. Hardhana, \& T. A. Soenardi, Eds.). Jakarta: Kementerian Kesehatan
Republik Indonesia.

Kementerian Kesehatan RI. (2015). Petunjuk Teknis Penggunaan Buku Kesehatan Ibu dan Anak. Jakarta: Kementerian Kesehatan Republik Indonesia.

Lawrence, R. A., \& Lawrence, R. M. (2010). Breastfeeding: A Guide for the Medical Professional (7th ed.). Missouri: Elsevier Mosby.

Mansyur, N., \& Dahlan, A. K. (2014). Buku Ajar Asuhan Kebidanan Masa Nifas. Malang: Selaksa Medika.

Manuaba, I. B. G. (2010). Ilmu Kebidanan, Penyakit Kandungan, dan KB untuk Pendidikan Bidan (2nd ed.). Jakarta: EGC.

Meihartati, T. (2017). Hubungan Antara Perawatan Payudara Dengan Kejadian Bendungan ASI (Engorgement) Pada Ibu Nifas. Jurnal Kebidanan Dan Keperawatan, 13(1), 19-24.

Santoso, S. D. H., Kusmiyati, Y., \& Margono. (2016). Jurnal: Jurnal Kesehatan Ibu Dan Anak, 9(1), 19-22.

Wahyuni, E. D. (2018). Asuhan Kebidanan Nifas dan Menyusui. Jakarta: Pusdik SDM Kesehatan.

Witt, A. M., Bolman, M., Kredit, S., \& Vanic, A. (2016). Therapeutic Breast Massage in Lactation for the Management of Engorgement , Plugged Ducts , and Mastitis. Journal of Human Lactation, 32(1), 123-131. https://doi.org/10.1177/089033441561 9439 